\title{
The European Court of Justice Allows Third Countries to Challenge EU Restrictive Measures
}

\author{
Case C-872/19 P, Venezuela v Council \\ Luigi Lonardo and Elisabet Ruiz Cairó
}

\section{INTRODUCTION}

In Venezuela v Council (Venezuela), the Grand Chamber of the Court of Justice of the European Union made a pronouncement on a procedural point: it held that Venezuela had locus standi to challenge restrictive measures adopted by the European Union (EU). This conclusion was based on the finding that a third country is a legal person for the purposes of the fourth paragraph of Article 263 TFEU. ${ }^{1}$

The judgment contributes to defining the autonomous EU constitutional space with regard to international law. In the light of the reasoning to justify such a decision, and of its likely consequences, this ruling is an expression of constitutional maturity: it sends the signal that the $\mathrm{EU}$ is confident in the robustness of its legal order to the extent that it is not afraid to permit challenges to its measures

L. Lonardo, University College Cork, llonardo@ucc.ie; E. Ruiz Cairó, University of Geneva, elisabet.ruizcairo@unige.ch. The authors would like to thank Carmen Martínez Capdevila (Universidad Autónoma de Madrid) for her comments on an earlier draft, as well as the editors and reviewers of EuConst for their useful suggestions.

${ }^{1}$ Previously, the Court recognised standing to challenge restrictive measures for natural persons (GC 30 November 2016, Case T-720/14, Rotenberg), companies (ECJ 6 October 2020, Case C134/19 P, Bank Refah Kargaran v Council), including companies controlled by third countries (ECJ 28 March 2017, Case C-72/15, Rosneft, GC 30 November 2016, Case T-89/14, Export Development Bank of Iran), and holders of public offices in third countries (Azarov, Yanukovych).

European Constitutional Law Review, 18: 114-131, 2022

(C) The Author(s), 2022. Published by Cambridge University Press on behalf of European Constitutional Law Review. This is an Open Access article, distributed under the terms of the Creative Commons Attribution licence (https://creativecommons.org/licenses/by/4.0/), which permits unrestricted re-use, distribution, and reproduction in any medium, provided the original work is properly cited. doi:10.1017/S1574019622000025 
even when these challenges come from states that are not liberal democracies. Since the choice to place trust in the rule of law and judicial protection is forcefully made by the Court itself, Venezuela is also an important form of institutional self-empowerment.

This case note first reviews the factual and legal background of the judgment and briefly summarises the findings of Advocate General Hogan and of the Grand Chamber. It then argues that this judgment strengthens the previous case law on the autonomy of the EU legal order by adding an element of openness to it. Further, the case note considers the role that three notions of international law (state immunity, reciprocity and comity) could play in the EU legal order and provides some reflections on the procedural aspects of this judgment.

\section{FACTUAL AND LEGAL BACKGROUND}

In view of the continuing deterioration of democracy, the rule of law and human rights in Venezuela, the EU adopted restrictive measures against that country. ${ }^{2}$ The measures were challenged by the Bolivarian Republic of Venezuela before the General Court of the European Union. This resulted in the 2019 judgment in Case $\mathrm{T}-65 / 18,{ }^{3}$ where the General Court rejected the action on procedural grounds, as it held that Venezuela had not demonstrated that it was directly concerned by the measures within the meaning of the fourth paragraph of Article 263 TFEU. For the challenge to be admissible, Venezuela needed to demonstrate both that it was a 'legal person' and that it was 'directly concerned' by the contested measures, to the extent that these were a regulatory act not entailing implementing measures.

${ }^{2}$ Decision (CFSP) 2017/2074, implemented by Council Regulation (EU) 2017/2063 of 13 November 2017 concerning restrictive measures in view of the situation in Venezuela OJ L 295/21. Art 2 of Regulation 2017/2063 prohibits 'to provide, directly or indirectly, technical assistance, brokering services and other services related to the goods and technology listed in the EU Common List of Military Equipment and to the provision, manufacture, maintenance and use of goods and technology listed in the Common Military List' and 'to provide, directly or indirectly, financing or financial assistance related to the goods and technology listed in the Common Military List'. Art. 3 states that it is prohibited 'to sell, supply, transfer or export, directly or indirectly, equipment which might be used for internal repression', 'to provide technical assistance and brokering and other services related to' that equipment, and 'to provide financing or financial assistance, including in particular grants, loans and export credit insurance, as well as insurance and reinsurance, related to' that equipment. Art. 6 states that it is prohibited 'to sell, supply, transfer or export, directly or indirectly, equipment, technology or software' identified in an Annex, except with the authorisation by a competent authority of a member state; and Art. 7 makes subject to such authorisation the provision of technical or financial assistance related to such equipment, technology, or software.

${ }^{3}$ ECJ 20 September 2019, Case T-65/18, Venezuela v Council. 
The General Court found that the challenged restrictive measures did not concern Venezuela directly, because they did not impose prohibitions on Venezuela, which was not a target mentioned in the Annex to the sanctions. At most, the contested measures only had indirect effects on that country: they 'targeted' Venezuela only insofar as they prohibited natural or legal persons of EU member states to provide goods and services to economic operators established in Venezuela. ${ }^{4}$ This finding made it unnecessary to examine whether that country was a legal person for the purposes of Article 263 TFEU.

On appeal, Venezuela challenged the General Court's decision. The Court raised of its own motion the question whether Venezuela was a legal person. The judgment hinged on that issue and, should the answer be in the affirmative, on whether Venezuela was directly concerned by the contested measures. On the legal personhood question, Venezuela argued that neither the wording of the fourth paragraph of Article 263 TFEU nor the objective or the context of that provision provide any indication - even indirectly - that would allow it to be excluded from the concept of 'legal person'. ${ }^{5}$ The Council argued that a third state should not be regarded as a 'legal person' within the meaning of the fourth paragraph of Article 263 TFEU unless specific rights had been conferred on it within the EU legal order by way of an agreement concluded with the EU (which was not the case in this instance). Granting standing to Venezuela, the Council contended, would 'unduly restrict the $\mathrm{EU}$ in the conduct of its policies and international relations'. ${ }^{6}$ The absence of reciprocity means that sovereign decisions of the EU could be challenged by a third state, but not the other way around. This would amount to conceding to third countries a way of solving international disputes which would be precluded to the EU. The Commission instead argued that if states voluntarily submit to the jurisdiction of the Court, a teleological interpretation of Article 263 TFEU does not prevent the Court from hearing such a case.

On the issue of direct concern, Venezuela argued that its not being listed in the Annex, or its not acting as economic operator, was irrelevant for the purpose of establishing that the contested measures directly affected it. It argued instead that, by prohibiting exports of certain items and services to Venezuela, the contested provisions had significant direct factual and legal effects against it. ${ }^{7}$ Venezuela also argued that the contested measures were regulatory acts not requiring implementing measures, and therefore individual concern was not a necessary condition to

${ }^{4}$ Ibid., paras. 31-33.

${ }^{5}$ ECJ 22 June 2021, Case C-872/19 P, Venezuela v Council, para. 25.

${ }^{6}$ Ibid., para. 29.

${ }^{7}$ ECJ 20 January 2021, Opinion of Advocate General Hogan, Case C-872/19 P, Venezuela v Council, para. 93. 
establish its standing. ${ }^{8}$ The Council, instead, argued that the General Court's reasoning was correct.

\section{The Opinion of the Advocate General}

The Opinion of Advocate General Hogan considered whether the appellant was a legal person for the purposes of the fourth paragraph of Article 263 TFEU and, since it answered in the affirmative, whether it was directly concerned by the restrictive measures in question, which was also answered in the affirmative, in explicit disagreement with the General Court.

On the legal personhood of Venezuela, the Advocate General argued that international practice and the associated principles of comity entailed that sovereign states should be able to sue in the courts of other sovereign states. ${ }^{9}$ Comity is a judicial tool frequently used by US tribunals that promotes cooperation between domestic courts and third states. It directs courts or tribunals to engage in acts of restraint or recognition, which can include discretionary abstention in a case where it is foreseen that it could result in jurisdictional conflicts with other courts, recognising judgments of foreign courts or tribunals, or presuming that foreign laws or acts are valid. ${ }^{10}$ In the case of Sabbatino, the US Supreme Court held that comity also allows sovereign states to sue in the courts of the United States. ${ }^{11}$ Advocate General Hogan held that comity also applies in the EU and allows third states to bring challenges before EU courts. It thus requires EU courts to admit that third states have legal standing under Article 263 TFEU. ${ }^{12}$

The European Court of Justice had incidentally considered whether a third country may bring an action under the fourth paragraph of Article 263 TFEU on previous occasions. ${ }^{13}$ The Court had interpreted broadly the notion of legal person for the purposes of that provision. Advocate General Hogan contended that the precedent of $P K K$ and $N K K \mathrm{v}$ Council ${ }^{14}$ suggested that the requirement of being a legal person was indeed not even a necessary condition to establish standing. He further argued that, if Venezuela could establish that it was directly and individually concerned by an EU measure, it 'must have access to the EU

${ }^{8}$ Venezuela v Council, supra n. 5, para. 89.

${ }^{9}$ Opinion of AG Hogan in Venezuela v Council, supra n. 7, para. 65.

${ }^{10} \mathrm{~T}$. Schultz and N. Ridi, 'Comity and International Courts and Tribunals', 50 Cornell International Law Journal (2017) p. 577 at p. 586.

${ }^{11}$ United States Supreme Court 23 March 1964, Banco Nacional de Cuba v Sabbatino 376 U.S. 398.

${ }^{12}$ Opinion of AG Hogan in Venezuela v Council, supra n. 7, para. 72.

${ }^{13}$ ECJ 10 September 2020, Case T-246/19, Cambodia v Commission, para. 51; ECJ 10 June 2009, Case T-257/04, Poland v Commission, paras. 51 and 52.

${ }^{14}$ ECJ 10 January 2007, Case C-229/05 P, PKK and NKK v Council. 
courts to protect its rights, irrespective of its legal qualification under national, international or perhaps indeed EU law. ${ }^{15}$

On the direct concern, the Advocate General voiced strong disagreement with the reasoning of the General Court, which he referred to as being highly artificial and unduly formalistic. ${ }^{16}$ First, Venezuela was directly included in the text of the restrictive measures because these prohibit the sale of equipment to 'any legal person, entity, or body (...) in Venezuela' (Articles 3, 6 and 7 of the contested measure), thus including 'Venezuela's government, public bodies, corporations or agencies, or any person or entity acting on their behalf or at their direction'. ${ }^{17}$ Second, the fact that ratione loci and ratione personae the restrictive measures only 'apply' on EU territory does not bear relevance for the issue of direct concern, as the sanctions clearly affect Venezuela's legal situation. ${ }^{18}$ This finding is also true for restrictive measures of general application, imposing obligations on persons and entities defined in abstract. ${ }^{19}$

Even though the restrictive measures challenged by Venezuela were 'a regulatory act and [were] thus sufficient to show that [Venezuela was] directly concerned by that measure', ${ }^{20}$ Advocate General Hogan concluded that 'the inclusion of persons or entities subject to restrictive measures in a list results in the persons or entities being both directly and individually concerned by the measures.' ${ }^{21}$

\section{THE JUdGMENT}

The Grand Chamber raised of its own motion the question whether Venezuela was a 'legal person' within the meaning of the fourth paragraph of Article 263 TFEU. It considered that the concept of 'legal person' should have an autonomous meaning in EU law since the Treaty does not refer to national law. The Court referred to its previous case law, which included under the broad concept of 'legal person' local or regional entities, ${ }^{22}$ private and public entities, ${ }^{23}$ and 'organisations without any legal personality under national law, EU law or international law'. ${ }^{24}$ Consistency and fairness required that if 'an entity has an

\footnotetext{
${ }^{15}$ Opinion of AG Hogan in Venezuela v Council, supra n. 7, para. 79.

${ }^{16}$ Ibid., para. 109.

${ }^{17}$ Ibid., para. 110.

${ }^{18}$ Ibid., para. 113.

${ }^{19}$ Ibid., fn. 86.

${ }^{20}$ Ibid., fn. 2.

${ }^{21}$ Ibid., para. 115 .

${ }^{22}$ ECJ 22 November 2021, Case C-452/98, Nederlandse Antillen.

${ }^{23}$ ECJ 1 February 2018, Case C-264/16 P, Deutsche Bahn and Others v Commission.

${ }^{24}$ Opinion of AG Hogan in Venezuela v Council, supra n. 7, para. 34, referring to PKK and NKKv Council, supra n. 14.
} 
existence sufficient for it to be subject to restrictive measures ( . . . that entity also has an existence sufficient to contest those measures'. ${ }^{25}$ Similarly, a teleological reasoning militated in favour of the conclusion that effective judicial review, designed to ensure compliance with the rule of law, should be interpreted as allowing a third country to bring proceedings as a legal person on par with other natural or legal persons. ${ }^{26}$ The Court added that the lack of reciprocity could not call into question that finding. ${ }^{27}$

The Grand Chamber also found that Venezuela was directly concerned by the contested measures. First, while it is true that the contested measures were formally addressed to EU operators, ${ }^{28}$ the fact that those operators were prohibited from carrying out certain transactions with Venezuela also implied that Venezuela was prohibited from carrying out those transactions with EU operators. ${ }^{29}$ The contested provisions were immediately and automatically applicable. ${ }^{30}$ Second, the wording of the contested provisions left no discretion to the addressees responsible for implementing them. ${ }^{31}$ The sanctions constituted a regulatory act not requiring implementing measures because they are non-legislative acts of general scope. ${ }^{32}$ Hence, individual concern is not necessary under the last sentence of the fourth paragraph of Article 263 TFEU and Venezuela did have standing to challenge the measures. For these reasons, the action brought by Venezuela was admissible and the Court referred the case back to the General Court for judgment on the merits.

\section{EVOLUTION OF THE EU LEGAL ORDER: FROM AUTONOMY TO OPENNESS}

The decision in Venezuela is a statement of principle on the role of the EU in international relations. ${ }^{33}$ It is an affirmation of distinctiveness, and therefore in line with the case law on the autonomy of the EU legal order. Previous cases show the Court's protectionist approach towards the EU constitutional sphere: the 'new legal order' recognised in Van Gend en Loos defined autonomy in a negative fashion: 'EU law is not public international law'. ${ }^{34}$ The EU legal system was later

\footnotetext{
${ }^{25}$ Venezuela v Council, supra n. 5, para. 47.

${ }^{26}$ Ibid., para. 50.

${ }^{27}$ Ibid., para. 52.

${ }^{28}$ Art. 20 of Regulation 2017/2063.

${ }^{29}$ Venezuela v Council, supra n. 5, para. 68.

${ }^{30}$ Ibid., para. 69.

${ }^{31}$ Ibid., para. 90.

${ }^{32}$ Ibid., para. 92.

${ }^{33}$ There is no doubt that the applicant in this case, the Bolivarian Republic of Venezuela, as a sovereign state, is a subject of international law.

${ }^{34}$ K. Lenaerts and J.A. Gutierrez Fons, 'A Constitutional Perspective', in R. Schutze and T. Tridimas, Oxford Principles of EU Law (Oxford University Press 2018) p. 105.
} 
'shielded' from international law. A legal manifestation of the principle of autonomy was articulated by the Court in the condition that a decision-making body outside the EU legal system 'must not have the effect of binding the EU and its institutions, in the exercise of their internal powers, to a particular interpretation of the rules of EU law. ${ }^{35}$ For example, in Opinion 1/17, the Court clarified that the Union (or a member state when implementing EU law) must not be in a position 'to amend or withdraw legislation because of an assessment made by a tribunal standing outside the EU judicial system. ${ }^{36}$ Similarly, as established in Kadi, the commitment to respect EU law, and in particular fundamental rights, will take precedence even over international law obligations of member states. ${ }^{37}$ The Court also limited the direct effect of international agreements in the EU legal order, by subjecting it to strict conditions. ${ }^{38}$

Yet, autonomy can also be shaped 'in a positive fashion': the EU legal order has a number of distinctive features that reveal its 'capacity to operate as a self-sufficient system of norms. ${ }^{39}$ The very existence of the EU Charter of Fundamental Rights (and the room for an autonomous interpretation under Article 52(3) of the Charter $\left.{ }^{40}\right)$, as well as other characteristics outlined in Opinion 2/13, is evidence of this 'positive' autonomy. ${ }^{41}$

While some decisions cushioned the EU legal order from actual or potential 'interference' from international law (defining autonomy 'in a negative fashion'), Venezuela tolerates acts which amount to external interference but do not adversely affect the autonomy of EU law. ${ }^{42}$ This judgment clarifies that the

${ }^{35}$ ECJ 18 December 2014, Opinion 2/13, para. 184; see also ECJ 14 December 1991, Opinion 1/91, paras. 30-35, and ECJ 18 April 2002, Opinion 1/00, para. 13.

${ }^{36}$ ECJ 30 April 2019, Opinion $1 / 17$, para. 150

${ }^{37}$ ECJ 3 September 2008, Joined Cases C-402/05 P and C-415/05 P, Kadi.

${ }^{38}$ See I. Hadjiyianni, 'The CJEU as the Gatekeeper of International Law: The Cases of WTO Law and the Aarhus Convention', 70(4) International and Comparative Law Quarterly (2021) p. 895.

${ }^{39}$ Lenaerts and Gutierrez Fons, supra n. 34, p. 106.

${ }^{40}$ ECJ 15 February 2016, Case C-601/15 PPU, $N$, para. 47: 'the explanations relating to Article 52 of the Charter indicate that paragraph 3 of that article is intended to ensure the necessary consistency between the Charter and the ECHR, without thereby adversely affecting the autonomy of Union law and ... that of the Court of Justice of the European Union'.

${ }^{41}$ ECJ 18 December 2014, Opinion 2/13, paras. 165-176. As stated by Lenaerts and Gutierrez Fons, supra n. 34, p. 106: 'the nature of EU law, the principle of mutual trust between the Member States, the system of fundamental rights protection provided for by the Charter of Fundamental Rights of the European Union, the substantive law of the EU that directly contributes to the implementation of the process of European integration, the principle of sincere cooperation, and the EU system of judicial protection of which the preliminary reference procedure provided for in Article 267 TFEU is conceived as the keystone' (internal references omitted).

${ }^{42}$ The interference is the fact that Venezuela can challenge an EU act. This is not a breach of the principle of autonomy because the interpretative monopoly of Court of Justice of the EU, or other essential characteristics of the EU, are not affected. 
EU constitutional order is not afraid to be put to the test, even when the legal challenge comes from a state which is not a liberal democracy and could thus be regarded as a political rival. ${ }^{43}$ The attitude may differ - defensive in previous cases, bolder in Venezuela - but the result is the same: a statement of the autonomy whereby the EU can carry out confidently and even assertively its foreign affairs, while fully respecting the core values of a Union based on the rule of law and respect for fundamental rights. One could thus read the judgment as suggesting that accepting challenges strengthens the EU foreign policy. This position contrasts with the Council's contention that allowing Venezuela to challenge sanctions would weaken the EU position in international relations, and shows confidence in the EU judicial system instead.

In allowing a third country to challenge EU law before EU courts, the Court of Justice of the European Union not only rejects a requirement of reciprocity, it also requires no form of quid pro quo from the international legal order for the protection of third countries' interests, self-reliantly taking on a challenging task. Yet, the Court does not go a step too far. First, the decision is a statement of principle because the innovative step is a procedural rather than a substantive one. The decision on the substance is referred back to the General Court. Second, the judgment does not put Venezuela on a par with member states (which are privileged applicants under Article 263 TFEU) or with other third countries on which the member states have decided to confer certain privileges. ${ }^{44}$

\footnotetext{
${ }^{43}$ Other ways in which international law permeates the EU legal order are the equivalence clause of Art. 52(3) Charter between the Charter and the European Convention on Human Rights; or the recognition that customary international law can be binding on the EU (ECJ 16 June 1998, Case C162/96, Racke). More generally, 'the ECJ strives to define the EU constitutional space, but without denying the fact that EU law influences and is influenced by the legal orders that surround it': Lenaerts and Gutierrez Fons, supra n. 34, p. 106.

${ }^{44}$ Such as the annex of the Agreement between the European Community and the Swiss Confederation on Air Transport (signed on 21 June 1999 in Luxembourg and approved by Decision 2002/309/EC, Euratom of the Council and the Commission, concerning the Agreement on scientific and technological cooperation of 4 April 2002 on the conclusion of seven agreements with Swiss Confederation, OJ/L 114, p. 1), considering the reference to member states as applying equally to Switzerland for the purposes of the Agreement. In ECJ 14 July 2005, Case C70/04, Swiss Confederation v Commission, paras. 17-24, the ECJ held that the case should be heard on the merits by the General Court, either because the Swiss Confederation could be assimilated to a member state, or to a natural and legal person under the fourth para. of Art. 263 TFEU. 'Consequently, the action was referred to the now General Court for adjudication, which dismissed the case on the merits without ruling on the admissibility: EGC, Case T-319/05, Swiss Confederation v Commission [2010] ECR II-4265, para. 55 (appeal dismissed without ruling on the question of admissibility at first instance: ECJ (judgment of 7 March 2013), Case C-547/ 10 P, Swiss Confederation v Commission, not reported)': K. Lenaerts et al., EU Procedural Law (Oxford University Press 2014) p. 313.
} 


\section{The Influence OF PUBlic INTERNATIONAL LAW ON EU FOREIGN AFFAIRS}

The Opinion and the Judgment in Venezuela invite reflections on the influence of public international law on EU foreign affairs. In Venezuela, both the Advocate General and the Grand Chamber refer to concepts of public international law, underlying that those can influence how the EU's external action, including the Common Foreign and Security Policy, is to be conducted. There are three concepts among the legal issues in Venezuela that can be examined from an international law perspective: the doctrine of state immunity; comity; and the principle of reciprocity.

The application of the doctrine of state immunity was raised by the Council and the European Commission, and was considered in Advocate General Hogan's Opinion. The Council argued that Venezuela had the right not to submit to the jurisdiction of the European Court of Justice unless it had consented to it. ${ }^{45}$ This argument is related to the international law doctrine of state immunity, according to which a sovereign state cannot be subjected to the proceedings of a foreign court unless it has consented to it. ${ }^{46}$ The European Commission's position was more nuanced. It made a distinction between acts carried out by the state in a private capacity (acta jure gestionis) and acts carried out in the exercise of state sovereignty (acta jure imperii), arguing that a state cannot be subjected to the jurisdiction of another state in relation to acts carried out in a sovereign capacity. ${ }^{47}$ This is in line with the understanding of state immunity found in public international law. ${ }^{48}$ However, as rightly pointed out by Advocate General Hogan, none of these arguments could be successful. The doctrine of state immunity aims at ensuring that a state cannot be sued before the courts of another sovereign state without its consent (légitimation passive). ${ }^{49}$ This doctrine does not limit the legal standing of Venezuela to bring an action against the Council before EU courts (légitimation active). ${ }^{50} \mathrm{~A}$ state has the right to bring proceedings before the courts and tribunals of another state. ${ }^{51}$

\footnotetext{
${ }^{45}$ Venezuela v Council, supra n. 5, para. 27.

${ }^{46}$ Art. 5 United Nations Convention on Jurisdictional Immunities of States and their Property,

${ }^{47}$ Venezuela v Council, supra n. 5, para. 37.

${ }^{48}$ ICJ 3 February 2012, Jurisdictional Immunities of the State (Germany v Italy: Greece intervening), ICJ Reports 2012, p. 99, paras. 59-61.

${ }^{49}$ Opinion of AG Hogan in Venezuela v Council, supra n. 7, para. 68.

${ }^{50}$ Ibid.

${ }^{51}$ Art. 8 United Nations Convention on Jurisdictional Immunities of States and their Property, New York, 2004; Art. 1 European Convention on State Immunity, Basel, 1972, ETS No 74. To date, only eight states have ratified the European Convention on State Immunity and 28 states have signed the New York Convention, so none of these instruments has yet entered into force. However,
} 2004. 
It is not the first time that the doctrine of state immunity has been invoked before the European Court of Justice. ${ }^{52}$ In Rina, the Court refused to extend state immunity to private undertakings even if they performed tasks entrusted by states. In Mahamdia, the Court affirmed that employment contracts concluded by the embassy of Algeria in Germany were not covered by state immunity, which did not extend to acts performed jure gestionis. ${ }^{53}$ From these rulings, it has been contended that the case law of the European Court of Justice tends to narrow down the scope of state immunity. ${ }^{54}$ Venezuela $\mathrm{v}$ Council does not add to that line of reasoning, as the Court correctly does not make any comment on immunity, but it is interesting to see how this principle is used by the different parties to the proceedings.

Principles of international comity are used by Advocate General Hogan to interpret the notion of 'legal person' under Article 263, fourth paragraph, TFEU. ${ }^{55}$ Advocate General Hogan argued that, in accordance with 'principles of international comity', the notion of 'legal person' should be interpreted as including third states that challenge EU measures in their sovereign capacity as international legal persons. ${ }^{56}$ Although the Court did not rule on this point, it deserves some attention, as it is unclear whether comity can really be considered a doctrine in public international law and, if so, whether it should have any weight on the Court's reasoning.

Comity presents opportunities for EU external action but it also raises some questions. Comity might constitute an interesting tool with which the EU could conduct its foreign relations, as it could positively shape EU relations with the outside world. ${ }^{57}$ By allowing third states to bring suits before EU courts, comity would enhance dialogue and create a cooperative environment between domestic courts and third states. For this reason, comity could contribute to some of the EU's objectives in its external relations. It could develop relations and build

state immunity is generally accepted as a principle of customary international law, as stated in Recital 1 of the New York Convention.

${ }^{52}$ See, among others, ECJ 7 May 2020, Case C-641/18 Rina; ECJ 19 July 2012, Case C-154/11, Mahamdia.

${ }^{53}$ Note, however, that in both cases the Court refers to state immunity as a customary principle of international law and not as an obligation deriving from any international agreement. The Advocate General in Rina does refer to the New York Convention in his Opinion.

${ }^{54}$ A. Spagnolo, 'A European Way to Approach (and Limit) the Law on State Immunity? The Court of Justice in the RINA Case', 5 European Papers (2020) p. 645 at p. 645.

${ }^{55}$ Opinion of AG Hogan in Venezuela v Council, supra n. 7, para. 65.

${ }^{56}$ Ibid.

${ }^{57}$ E. Kassoti, 'State Immunity, Comity and the Question of Legal Standing of a Third Country before the CJEU: The Opinion of AG Hogan in Case C-872/19 P Venezuela v Council', EU Law Analysis, 9 April 2021, 〈http://eulawanalysis.blogspot.com/2021/04/state-immunity-comity-andquestion-of.html $\rangle$ visited 27 January 2022. 
partnerships with third countries and international organisations. ${ }^{58}$ It could also promote 'an international system based on multilateral cooperation and good global governance. ${ }^{59}$ Additionally, by promoting dialogue between domestic and foreign courts, comity could also solve some of the conflicts raised by the proliferation of international courts and tribunals. ${ }^{60}$

However, the reasoning of Advocate General Hogan on comity raises several questions. First, comity seems to be, for the time being, a domestic law doctrine. ${ }^{61}$ It is mainly used by the US Supreme Court to recognise foreign law and foreign judgments, and to allow foreign states to bring suits as plaintiffs before domestic courts. It is also used to limit the reach of American law and the jurisdiction of American courts over foreign sovereign defendants. ${ }^{62}$ Yet, Advocate General Hogan did not elaborate on how this US doctrine had been integrated in the EU legal order. Second, reliance on principles of comity to admit the possibility for third states to bring challenges before the Court of Justice of the European Union could also raise reciprocity concerns, as foreign courts might not be as cooperative with EU member states and the EU itself.

Reciprocity concerns were precisely mentioned by the Council in Venezuela and briefly examined by the Court in its judgment. Reciprocity is considered a basic principle of international law, since there is no overarching legal authority enforcing the law of nations. ${ }^{63}$ Reciprocity is also an important concept governing relations between the EU and third countries. An important body of case law in this regard concerns the review of legality of EU acts in light of World Trade Organisation agreements. In Portugal v Council, the Court denied the possibility of reviewing EU acts against World Trade Organisation agreements based on lack of reciprocity, as some contracting parties did not consider such agreements to be among the rules in light of which the legality of domestic law could be reviewed. ${ }^{64}$

${ }^{58}$ Art. 21(1), second paragraph, TEU.

${ }^{59}$ Art. 21(2)(h) TEU.

${ }^{60} \mathrm{~T}$. Schultz and N. Ridi, 'Comity and International Courts and Tribunals', 50 Cornell International Law Journal (2017) p. 577 at p. 588.

${ }^{61}$ W.S. Dodge, 'International Comity in American Law', 115 Columbia Law Review (2015) p. 2071 at p. 2074. Dodge defines comity as 'deference to foreign government actors that is not required by international law but is incorporated in domestic law' (p. 2078).

${ }^{62}$ Ibid., p. 2099.

${ }^{63} \mathrm{~F}$. Paris and N. Ghei, 'The Role of Reciprocity in International Law', 36 Cornell International law Journal (2003) p. 93 at p. 119-120; M. Byers, Custom Power and the Power of Rules: International Relations and Customary International Law (Cambridge University Press 1999) p. 89-90; J. Shen, 'The Basis of International Law: Why Nations Observe', 17 Dickinson Journal of International Law (1999) p. 287 at p. 354-355. Reciprocity was also considered one of the basic principles of international law by some of the member states participating in the proceedings in Venezuela v Council; see Venezuela v Council, supra n. 5, para. 32.

${ }^{64}$ ECJ 23 November 1999, Case C-149/96, Portugal v Council, paras. 43-45. 
Reciprocity was also used by Advocate General Bot in Opinion 1/17 to justify the lawfulness of the Investor-State Dispute Settlement mechanism established in the Comprehensive Economic and Trade Agreement. He affirmed that reciprocity was 'one of the guiding principles of the EU's external relations'. ${ }^{65}$ He further argued that the EU could not base its relations with third states on mutual trust and that, when negotiating an agreement with a third state, the EU needed to ensure that reciprocity would apply. ${ }^{66}$ Reciprocity is therefore a concept that is frequently relied upon in EU external relations law, and the reasoning of the Council is in line with that case law.

However, the Court rejected the idea that reciprocity concerns should dictate the Court's conclusions in Venezuela, by affirming that respect for the rule of law should prevail over any reciprocity concerns. ${ }^{67}$ This is justified in light of the legal background of the judgment in Venezuela and its differences from the above-mentioned case law. First, Portugal v Council and Opinion 1/17 deal with the Common Commercial Policy, whereas Venezuela concerns restrictive measures. Reciprocity, the case law appears to say, is a relevant consideration in the former area, not in the latter. This seems in line with the Court's belief that some fields of external action (such as trade and investment) are 'based on reciprocal and mutually advantageous arrangements, ${ }^{68}$ whereas others (such as the protection of fundamental rights ${ }^{69}$ ) are not. Second, the previous cases concerned access to courts by individuals and companies, not by a state. The lack of reciprocity in the Venezuela scenario would simply entail that, if Venezuela adopted sanctions against the EU, member states would not be allowed to challenge those measures in Venezuela's courts. ${ }^{70}$ Other economic operators, such as EU companies, might still be able to do so, and this would presumably be a question of Venezuelan procedural law. In other words, the absence of reciprocity is unlikely to have a serious economic impact on EU economic operators. Third, both in Portugal v Council and in Opinion 1/17, the reciprocity argument was raised with regard to an international agreement concluded between the EU and third states. By contrast, there is no such international agreement in Venezuela. Instead, the case concerns a unilateral act of the EU. This means that the reciprocity argument in Venezuela has a purely hypothetical nature. Venezuela has not imposed any

${ }^{65}$ ECJ 29 January 2019, Opinion 1/17, Opinion of AG Bot, para. 77.

${ }^{66}$ Ibid., para. 82.

${ }^{67}$ Venezuela v Council, supra n. 5, para. 52.

${ }^{68} 8$ May 204, Opinion of AG Jääskinen in Joined Cases C-401/12 to C-403/12 P, Council and Others v Vereniging Milieudefensie and Stichting Stop Luchtverontreiniging Utrecht, para. 88.

${ }^{69}$ Ibid., para. 89.

${ }^{70}$ In fact, the Council raised the issue that the EU itself would not be able to challenge measures adopted by Venezuela. But this is not, strictly speaking, what reciprocity would mandate, as the question was whether a sovereign state can sue in other domestic courts. 
restrictive measures on the EU, so whether the EU or its member states could bring actions before Venezuelan courts is a much more remote question than, say, the (lack of) reciprocity afforded by a state who is an EU contracting partner and with whom there is already an agreement in place. The Court did not elaborate on these arguments and simply stated that the obligation to preserve the rule of law should prevail over any reciprocity concerns. The decision not to require reciprocity in this case is, therefore, a conscious choice to underline the importance of EU values, notably the rule of law and the principle of effective judicial protection.

\section{Procedural law and judicial protection in the context of EU SANCTIONS}

\section{Is a third country a legal person?}

The finding that a country is a legal person for the purposes of Article 263, fourth paragraph, TFEU is convincing and unsurprising. First, since the concept of legal person has 'autonomous meaning' under EU law, and in the absence of decisive textual arguments, the principle of effective judicial protection broadly understood, as a dimension of the principle of the rule of law, ${ }^{71}$ strongly militates in favour of the conclusion that a third country is a legal person. ${ }^{72}$ If a third country could never fulfil this necessary (but not sufficient) condition to have standing in EU courts, access to judicial review in the form of direct actions would be precluded them. ${ }^{73}$ Alternative findings, such as that a third country is a privileged or

\footnotetext{
${ }^{71}$ Which encompasses 'the availability of judicial review to test the legality of the exercise of public power'; K. Armstrong, 'The Open Method of Coordination: Obstinate or Obsolete?' in Schütze and Tridimas, supra n. 34, p. 803. The fact that states have rights is well established in international law (see the material in the special issue 'The Rights of States in International Law', 4(3) Cambridge Journal of International and Comparative Law (2016)) and EU law (as both parties agreed in Venezuela: see Opinion of AG Hogan, supra n. 7, para. 35). In particular, since Art. 47 of the Charter is a derivative right, if a state could not rely on it this would mean that a state's primary rights could be always limited as no judicial claims could be made by the state concerned. ECJ 9 July 2020, Case C-575/18 P, Czech Republic v Commission supports the conclusion that a (member) state can rely on Art. 47 Charter.

${ }^{72} \mathrm{And}$ so are other non-state entities, as shown by the case law recalled by the Opinion of AG Hogan in Venezuela v Council, supra n. 7, para. 34.

${ }^{73}$ The third country might also not have standing under the procedural law of a member state, thus precluding also the challenge via preliminary ruling. It is true that ' $[t]$ he rules of national law relating to an individual's locus standi and interest in bringing proceedings may not detract from the full effectiveness of Union law' (Lenaerts et al., supra n. 44, p. 119), but whether such effectiveness requires that a state be considered a legal person is quod erat demonstrandum.
} 
semi-privileged applicant, would probably be contrary to the Treaties. ${ }^{74}$ Second, a systematic argument also points in the same direction: the legal basis of the contested measure (Article $215 \mathrm{TFEU}$ ) states that necessary provisions on legal safeguards must be included in the restrictive measures - regardless of whether the target is a third country, a natural or legal person, or a non-state actor. Third, the finding is also in line with public international law ${ }^{75}$ and many domestic legal systems. $^{76}$

\section{What is a regulatory act?}

For the purposes of the fourth paragraph of Article 263 TFEU, there are specific rules for regulatory acts. These can be challenged by applicants who are directly concerned, without there being a need to establish that the applicants are individually concerned. This category was introduced by the Lisbon Treaty precisely to ease citizens' direct access to EU courts. ${ }^{77}$ The case law has clarified that the conditions relating to the regulatory nature of the contested act, to the applicants being directly concerned, and to the absence of implementing measures are cumulative. ${ }^{78}$ The first of those three conditions is considered here; the second is discussed in the next paragraph.

The Court has established that a regulatory act refers to acts of general application and does not include legislative acts. ${ }^{79}$ Restrictive measures are non-legislative acts. If they are contained in a decision on common foreign and security

${ }^{74}$ Such a finding would arguably have violated the principle of institutional balance codified in Art. 13(2) TEU, as it would have encroached on the prerogatives of other institutions, which are in charge of negotiating international agreements with - and thus can confer privileges on - third countries.

${ }^{75} \mathrm{~J}$. Crawford, Brownlie's Principles of Public International Law, 8th edn. (Cambridge University Press 2019) p. 115.

${ }^{76}$ E. Gliozzi, 'Persona Giuridica', in Enciclopedia delle Scienze Sociali (Treccani 1996); E. Maulin, La théorie de l'État de Carré de Malberg (Leviathan, Presses Universitaires de France 2003) p. 143197; L. López Rodó, 'La personalidad jurídica del Estado', 59 Anales de la Real Academia de Ciencias Morales y Politicas (1982) p. 343.

${ }^{77}$ ECJ 6 November 2018, Joined Cases C-622/16 P to C-624/16 P, Montessori, para. 26. The Court has adopted a strict reading of direct concern in competition law or in anti-dumping procedures, for example; see V. Luszcz, European Court Procedure: A Practical Guide (Hart Publishing $2020)$ at $\$ 3.145$. The author mentions notably ECJ 17 September 2015, Joined Cases C-455/13 P, C-457/13 P and C-460/13 P, Anicav, para. 49; ECJ 28 April 2015, Case C-456/13 P, T\&́L Sugars, para. 37; Montessori, supra n. 76, para. 46; ECJ 28 February 2019, Case C-466/16 P, Marquis Energy, paras. 56-57.

${ }^{78}$ GC 19 November 2020, Case T-32/20, Buxadé Villalba and Others v Parliament, para. 30.

${ }^{79}$ ECJ 3 October 2013, Case C-583/11 P, Inuit Tapiriit Kanatami and Others v Parliament and Council, paras. 60-61. In Montessori, supra n. 76, para. 28, the Court stated that regulatory acts are 'all non-legislative acts of general application', whereas the General Court in GC 21 June 2021, Case T-252/20, Silver, para. 78, adopted a narrower view. 
policy, this cannot be a legislative act, as Article $24 \mathrm{TEU}$ precludes it. If they are contained in a TFEU regulation, and thus adopted under the non-legislative procedure laid down in that provision, they cannot be regarded as a legislative act either. ${ }^{80}$ It follows that if restrictive measures are of general application, meaning that they have a 'general scope' and affect the applicants by reason of their objective status, ${ }^{81}$ then they are regulatory acts.

\section{When is a third country directly concerned by restrictive measures?}

The conclusion that Venezuela is directly concerned by the sanctions may sit uncomfortably with the finding in Rosneft, ${ }^{82}$ that the Court does not have jurisdiction on decisions on common foreign and security policy containing measures of general application. ${ }^{83}$ In Rosneft, the Court did not scrutinise the Council's political choice to target the Russian oil sector because it considered it a measure of general application; ${ }^{84}$ in Venezuela, instead, the Court was prepared, at least potentially, to assess the merit of the Council's political decision to target Venezuelan technology or equipment capabilities - which, however, could also be considered of general application. ${ }^{85}$

In Venezuela, the Court's jurisdiction was beyond doubt: ${ }^{86}$ the contested measures were contained in a TFEU regulation, not in a decision on common foreign

${ }^{80}$ Venezuela v Council, supra n. 5, para. 92.

${ }^{81}$ Ibid., para. 92

${ }^{82}$ Rosneft, supra n. 1, para. 99.

${ }^{83}$ The discussion of the point in Rosneft was necessary because it is necessary to ascertain what constitutes a decision proving for restrictive measures, for the purposes of establishing the Court's jurisdiction (Art. 275 TFEU), which is as a general rule limited in the context of common foreign and security policy (Art. 24 TEU).

${ }^{84}$ In Rosneft, one of the measures (Art. 4a(1) Decision 2014/512/CFSP) was worded as follows: 'The direct or indirect provision of associated services necessary for [certain] categories of exploration and production projects in Russia, including its Exclusive Economic Zone and Continental Shelf, by nationals of Member States, or from the territories of Member States, or using vessels or aircraft under the jurisdiction of Member States shall be prohibited'. That measure was considered of general application - and therefore outside the Court's jurisdiction: Art. 4a(1) Decision 2014/512/CFSP: Rosneft, supra n. 1, para. 98.

${ }^{85}$ Art. 6 of the contested Regulation in Venezuela: 'It shall be prohibited to sell, supply, transfer or export, directly or indirectly, equipment, technology or software identified in Annex II, whether or not originating in the Union, to any person, entity or body in Venezuela or for use in Venezuela [unless prior authorisation has been obtained].' It is submitted that both the Rosneft and the Venezuela provisions considered 'prohibit general and abstract categories of addressees from carrying out certain transactions with entities which are also referred to in a general and abstract manner', to use the formulation of the Court in Venezuela, para. 92. In Rosneft, supra n. 1, para. 99, the applicant had also submitted that it was directly affected by those measures.

${ }^{86}$ Opinion of AG Hogan in Venezuela v Council, supra n. 7, paras. 60-61. 
and security policy. ${ }^{87}$ But, hypothetically, what if a third country were to challenge a similarly worded provision contained in a decision on common foreign and security policy (as opposed to a TFEU regulation)? Following Venezuela, the country might be directly concerned by that measure (or might be the addressee of that act), which however, following Rosneft, would fall outside the Court's jurisdiction. In other words, access to judicial protection against acts with the same effect would depend on the legal basis of the act, but this may in turn be incompatible with the obligation of the EU to ensure respect for the rule of law, and in particular with effective judicial review. Whether an entity is affected or not by an EU act is independent of whether the measure is provided for in a decision on common foreign and security policy or in a TFEU regulation. The inconsistency is not purely theoretical, and it may hinder effective judicial review. The existence of a decision on common foreign and security policy does not impose an obligation on the Council to adopt an Article 215 TFEU regulation, ${ }^{88}$ and in any case, the two instruments may not be identically worded, ${ }^{89}$ so the entity may not always be in a position to challenge the measure contained in the TFEU act.

\section{Conclusion}

The judgment in Venezuela is an expression of the autonomy and consequent confidence of the $\mathrm{EU}$ as an actor in the global scene. By allowing third states to bring proceedings before EU courts, the Court of Justice of the European Union contributes to fashioning the positive aspect of autonomy, shaping the EU constitutional sphere by implying that the EU is sufficiently confident to allow this kind of challenge. The resulting vision of autonomy could be criticised, as it allows third countries to challenge the fruit of (democratic) enactments of EU institutions, and opens the door to potential abuses: a third country - especially one subject to restrictive measures for violating human rights and EU values - could bring proceedings in a tendentious way. It could use judicial review strategically, to tamper with the EU democratic process. There is perhaps a risk that an ill-

\footnotetext{
${ }^{87}$ For the rule that the Court has jurisdiction over a TFEU regulation implementing a decision on common foreign and security policy, see Rosneft, supra n. 1, para. 106. Yet the Commission, at the oral hearing in Rosneft, submitted that the Court should not have jurisdiction over Regulations implementing decisions on common foreign and security policy which are actes de gouvernement.

${ }^{88}$ ECJ 6 September 2013, Case T-35/10 and Case T-7/11, Bank Melli Iran v Council, paras. 193-194.

${ }^{89}$ The need to ensure consistent judicial protection against measures contained in common foreign and security policy and TFEU acts was also at the basis of the decision in Bank Refah Kargaran, supra n. 1, para. 39, where the Court considered that it would be undesirable to restrict its jurisdiction to rule on the harm allegedly caused by restrictive measures only to cases in which those measures are provided for in a TFEU act.
} 
intentioned country might use EU law against the EU itself. The work of EU institutions would be put to a test - and the resources of the European Court of Justice would be squandered at the capricious will of countries who may be acting in bad faith. However, the mere risk of abuse is not a sufficient reason to deny the opportunity of judicial review.

Venezuela also constituted a rare opportunity to determine the role, in the EU legal order, of certain concepts of international law: state immunity, comity, and reciprocity. The Court did not seize that opportunity, as it did not elaborate on those concerns in as much detail as the parties and the Advocate General did. However, the arguments presented by the parties in the proceedings and the Opinion of Advocate General Hogan are enlightening in this regard, and reflect on how some principles of international or foreign (US) law can be incorporated into the EU legal order. The Court may need to take a clearer stance on these principles in future judgments.

Venezuela is also of interest from the perspective of judicial protection in the area of restrictive measures. What the decisions in Rosneft, Bank Refah Kargaran and Venezuela have in common is a reliance on teleological reasoning based on effective judicial protection, on the value of the rule of law, and on the consistency of the system of judicial protection in the EU. This reasoning leads to a muscular protection of the procedural rights of applicants seeking to challenge sanctions. In Rosneft, the Court for the first time allowed an applicant (in that case, a third country-owned company) to challenge the validity of restrictive measures through the preliminary ruling procedure. In Bank Refah Kargaran, ${ }^{90}$ the Court admitted for the first time an action for damages for the harm caused by a decision on common foreign and security policy on restrictive measures against a third country bank. In Venezuela, it was not the procedural avenue that was enlarged, but the very pool of potential challengers of restrictive measures, since the Court acknowledged that third countries may have locus standi to do so. ${ }^{91}$ This teleological reasoning is typical of post-Lisbon judgments delivered in the context of common foreign and security policy, ${ }^{92}$ and has also resulted in more or less major departures from the text of the Treaties, in so far as the Court has established an overall broad jurisdiction over common foreign and security policy measures

${ }^{90}$ Bank Refah Kargaran, supra n. 1.

${ }^{91}$ The opening up of the pool of potential applicants also comes with limitations: third countries would encounter the TWD limitation, meaning that they would be barred from challenging via preliminary rulings the validity of measures they could challenge via direct action, once the terms for introducing the latter have expired.

${ }^{92} \mathrm{P}$. Koutrakos, 'Judicial Review in the EU's Common Foreign and Security Policy', 67 International and Comparative Law Quarterly (2018) p. 1; G. Butler, 'The Coming of Age of the Court's Jurisdiction in the Common Foreign and Security Policy',13 EuConst (2017) p. 673. 
in direct and indirect actions, ${ }^{93}$ as well as in actions for damages. ${ }^{94}$ In the case under analysis, the same reasoning, applied to Article 263 TFEU, warrants a more liberal interpretation of locus standi than the Council argued for, but no departure from a literal interpretation of the Treaty was needed. ${ }^{55}$ In previous cases, the applicants who benefited from such a reasoning were natural persons, companies, or emanations of the state. The reasoning has now been applied for the benefit of third countries and this novelty, if unsurprising, is remarkable, as it is evidence of the progressive openness of the EU legal system.

${ }^{93}$ Rosneft, supra n. 1.

${ }^{94}$ Bank Refah Kargaran, supra n. 1.

${ }^{95}$ It should be recalled that in Venezuela the contested measure was not a decision on common foreign and security policy, but a TFEU regulation, over which the Court's jurisdiction is broader and established beyond doubt. 